\title{
American General Jurisdiction Trial Courts: New Visions, New Guidelines
}

\author{
Jeffrey A. Parness
}

Having abandoned the exclusive focus on adjudication to embrace the whole dispute process, the courts have launched themselves on a voyage over seas that can be charted only with instruments still to be fashioned.

The most firmly implanted myth of procedural reform may be that we can talk usefully about it as simply an effort to increase judicial efficiency, without talking about our visions of procedural and social justice.

\section{INTRODUCTION}

A new age in civil litigation has dawned for American trial courts of general jurisdiction. The traditional role involving neutral, detached, and passive judges, who look to adversaries in private-party civil actions to prepare cases for later courtroom trials on pleaded claims, has given way to proactive judges who direct disputes toward resolution, increasingly through court-mandated hearings beyond their own courtrooms and judicially managed settlements. As a result, new written guidelines have appeared for federal and state trial judges who now more frequently oversee extrajudicial (but court-sponsored) settlement discussions, who preside over judicial settlement conferences, and who help facilitate private settlement talks. Today, written laws on trial increasingly coexist with written laws on settlement. New written norms on extrajudicial hearings have emerged that address court-compelled and court-assisted mediations and arbitrations, as well as on aspects of judicial settlement conferences including compelled participation, contract formation, and

\footnotetext{
* Professor of Law, Northern Illinois University College of Law. Visiting Professor, Washington and Lee University School of Law, 2006-2007. B.A., Colby College; J.D., The University of Chicago Law School. Thanks to Josh Smith for his excellent research assistance.

1. Marc Galanter \& Mia Cahill, "Most Cases Settle": Judicial Promotion and Regulation of Settlements, 46 STAN. L. REV. 1339, 1391 (1994).

2. John Leubsdorf, The Myth of Civil Procedure Reform, in CIVIL JustiCE IN CRISIS: Comparative Perspectives of Civil Procedure 53, 67 (Adrian A.S. Zuckerman ed., Oxford Univ. Press 1999).
} 
contract enforcement. Some new guidelines have also emerged on the judicial oversight of aspects of wholly private settlement talks, including insurance adjuster conduct and settlement enforcement.

These new guidelines on civil case settlements have arisen in civil procedure rules, professional responsibility standards (for attorneys and for judges), and occasionally in substantive statutory laws. In the absence of written norms, inherent judicial-power principles sometimes are employed. However, the elusive nature of inherent power has caused much confusion, leading to doubt and unevenness where certainty and uniformity are desired and achievable. Inherent power is less necessary, of course, where written laws operate. And certainly, uniformity and certainty are promoted by explicit written laws. The new civil litigation age has not, however, ushered in adequate new written laws on judicial settlement conferences. Civil litigation laws anticipating trials between named parties on pleaded claims continue to dominate, though proactive trial judges increasingly facilitate settlements involving nonparties and unpleaded claims. So, contemporary laws now reflect more "legend" and less "reality."

Similarly, though to a lesser extent than for settlement, today there are inadequate written norms for trial court review of private arbitrations and agency adjudications. For the former, there are vexing issues on the lines dividing trial judge and arbitrator responsibilities. For the latter, there are challenging issues on the level of judicial deference to agency interpretation of statutes the agency administers, as well as on the scope of judicial review of agency factfinding.

There is today a need for additional written guidelines on alternative nonevidentiary and evidentiary hearings designed to prompt settlements as well as on judicial and private settlement conferences. Similarly, there is a need for new guidelines on trial court review of private arbitrations and administrative agency adjudications. ${ }^{4}$ The adoption of such standards would be greatly facilitated if the American Bar Association (ABA) were to revise the general description of the trial judge's role in civil litigation, set forth in materials such as the Model Code of Judicial Conduct and the Standards Relating to Trial Courts.

3. See Peter L. Murray, The Disappearing Massachusetts Civil Jury Trial, 89 MASS. L. REV. 51, 60 (2004) (explaining that statistics show lawyers and judges are experiencing a different legal culture than that of fifty years ago).

4. See, e.g., Richard L. Marcus, Reform Through Rulemaking?, 80 WASH. U. L.Q. 901, 903 (2002) ("Modest reform is possible, and . . . inability to deliver revolutionary change may not be a bad thing."); Laurens Walker, The Other Federal Rules of Civil Procedure, 25 Rev. LiTig. 79, 80 (2006) (explaining that there is a "rich context of common law procedural rules," the "Other Rules," that function in conjunction with written rules). 
The descriptions of American trial judges and courts, and the lawyers and others working with them, too often exclude significant avenues of civil case resolution and significant review responsibilities of trial court judges. If general visions of American trial courts are limited, written laws on these same trial courts might address only those matters envisioned rather than all matters of import. New written guidelines on civil case settlement and court review of private arbitrations and agency adjudications would be easier to implement if, for example, current efforts to rewrite the Model Code of Judicial Conduct encompassed a broader and more accurate vision of trial court responsibilities.

The traditional role of general jurisdiction trial courts in civil litigation will first be explored. In particular, the articulated visions of the Model Code of Judicial Conduct and the Standards Relating to Trial Courts, as well as the 1938 Federal Rules of Civil Procedure (FRCP), will be examined. Next, the new trial court role will be described, where there is an expectation of fewer trials, more judicially managed settlements, and more appellate review of civil claim resolutions initially made elsewhere. Finally, some possible new guidelines on civil case settlement and on trial court review responsibilities will be posited, following an illustration of the unfortunate consequences that flow from a lack of general and particular codified norms.

\section{THE Visions OF GENERAL JURISDICTION TRIAL COURTS IN CIVIL LITIGATION}

In exploring the challenges facing trial judges in the vastly expanding arena of public-law litigation, Professor Abram Chayes nicely described the judicial role in "our traditional conception" of private-law litigation. ${ }^{5}$ Customarily, on the civil side, "a lawsuit is a vehicle for settling disputes between private parties about private rights." ${ }^{\text {The }}$ defining features of traditional civil litigation of private disputes are:

1. "The lawsuit is bipolar," involving a contest between two adverse parties "diametrically opposed" wherein any decision would be "on a winner-takes-all basis.",

5. Abram Chayes, The Role of the Judge in Public Law Litigation, 89 HARV. L. REV. 1281, $1282(1976)$.

6. Id.

7. Id. 
2. Private civil litigation is "retrospective" in that it concerns "an identified set of completed events."

3. "Right and remedy are interdependent," so that any relief afforded is "derived more or less logically from the substantive violation" that prompted the lawsuit. ${ }^{9}$

4. A private-rights lawsuit is "a self-contained episode" so that the impact of any judgment "is confined to the parties" and normally "the judgment ends the court's involvement."

5. The civil-litigation process employed to resolve a private dispute is "party-initiated and party-controlled" so that the trial judge is "a neutral arbiter of [party] interactions who decides questions of law only if they are put in issue."11

This perspective continues to dominate many judicial-conduct and trial-court standards guiding civil cases. ${ }^{12}$ ABA pronouncements, as well as the most significant written civil procedure norms, the FRCP, are chiefly guided by this "traditional conception" of private litigation wherein "private parties" and their "private rights" are at issue.

To govern judicial conduct, the ABA initially adopted the Canons of Judicial Ethics on July 9, 1924 ("1924 Canons"). ${ }^{13}$ The Canons were superseded by the Code of Judicial Conduct, adopted by the ABA in 1972 ("1972 Code") 14 and revised and adopted in the 1990 Model Code of Judicial Conduct ("1990 Code"). ${ }^{15}$ The later Code more closely followed the traditional judicial role envisioned by Professor Chayes.

8. Id.

9. Id.

10. Id. at 1283 .

11. Id.

12. See David A. Sklansky \& Stephen C. Yeazell, Comparative Law Without Leaving Home: What Civil Procedure Can Teach Criminal Procedure, and Vice Versa, 94 GeO. L.J. 683, 698 (2006) (notwithstanding Chayes's claim "that civil suits affecting 'only private interests' were a dwindling species, ... [ [t]he notion that civil litigation is first and foremost an arena for the adjudication of private disputes - disputes in which the public plays no role aside from providing a neutral arbitrator-proved remarkably durable").

13. CANONS OF JUdiCIAL ETHICS (1924).

14. CODE OF Judicial CONDUCT (1972).

15. MOdel CODE OF JUdicial CONDUCT (1990). 
The 1924 Canons declared "ethical standards" in the hope they would "become habits of life" for judges. ${ }^{16}$ However, these canons simply described appropriate judicial behavior in broad terms without detailing the range of judicial duties. Thus, Canon 5, on essential conduct, declared a judge should be "temperate, attentive, patient, impartial and ... studious of the principles of the law and diligent in endeavoring to ascertain the facts."17 Canon 19, on judicial opinions, stated a trial judge "should indicate reasons" when "disposing of controverted cases," thereby showing no serious arguments of counsel were "disregarded or overlooked"; demonstrating the judge's "full understanding"; promoting "confidence"; and avoiding any "suspicion of arbitrary conclusion." 18 Additionally, Canon 34, summarizing judicial obligation, noted that a judge should be "above reproach" as well as "conscientious, studious, thorough, courteous, patient, punctual, just, impartial, fearless of public clamor . . . and indifferent to private political or partisan influences." 19

The 1924 Canons were superseded on August 16, 1972 when the ABA adopted the Code of Judicial Conduct. ${ }^{20}$ Unlike the 1924 Canons, the 1972 Code spoke to a range of judicial duties. Canon 3, on the impartial and diligent performance of the duties of a judicial office, set forth "standards." 21 These standards were divided into categories of judicial duties, including adjudicative responsibilities; administrative responsibilities (involving, in part, the direction of staff and court officials); disqualification (involving grounds for questioning judicial impartiality); and remittal of disqualification (involving waivers of certain bases for judicial disqualification). ${ }^{22}$

Within the section on adjudicative responsibilities, the 1972 standards, at times, were sufficiently broad to cover judicial conduct on and off the record and to encompass decision making responsibilities that extended beyond pleaded claims and named parties. Thus, one standard stated a judge "should maintain order and decorum in proceedings." 23 Another required a judge to be "patient, dignified, and courteous" to litigants, lawyers, and "others with whom" the judge "deals" in an

16. CANONS OF JUdicial ETHICS pmbl. (1924).

17. Id. at Canon 5. Canon 5 referred to a judge in the masculine until 1957. Id.

18. Id. at Canon 19.

19. Id. at Canon 34.

20. Code OF Judicial CONDUCT (1972).

21. Id. at Canon 3.

22. Id. at Canon 3A-D.

23. Id. at Canon $3 \mathrm{~A}(2)$. 
"official capacity." 24 Yet another required a judge to "accord to every person who is legally interested in a proceeding . . . full right to be heard according to law. 25

In August 1990, the ABA revised the 1972 Code. Under the new Model Code of Judicial Conduct, Canon 3 continues to address the impartial and diligent performance of judicial duties and set forth "standards." 26 The specific judicial duties in 1990 were said to include adjudicative responsibilities, administrative responsibilities, disciplinary responsibilities, and disqualification. ${ }^{27}$ Many of the standards from the 1972 Code remained. The 1990 Code continued to speak of "proceedings" before the judge, ${ }^{28}$ responsibilities to "others" beyond litigants, jurors, witnesses, and lawyers, ${ }^{29}$ and "the right to be heard" for "every person" who has a legal interest in a proceeding. ${ }^{30}$

Unfortunately, however, many of the 1972 standards were replaced in 1990 by standards that did not address trial court duties beyond pleaded claims and named parties. For example, while the 1972 Code declared a judge "should dispose promptly of the business of the court," 31 the 1990 Code said a judge "shall dispose of all judicial matters promptly, efficiently, and fairly." 32 The accompanying 1972 Code commentary spoke of punctuality "in attending court" and expedition "in determining matters under submission." 33 The relevant 1990 Code commentary not only repeated those admonitions, but also spoke of extending "due regard for the rights of parties," of monitoring and supervising "cases," and of facilitating settlements by "parties." 34 These additional directives describe judicial duties more narrowly, limiting them to "cases," a term of art that often does not embody all of the disputes within a civil lawsuit, and to "parties," another term of art that typically excludes many who have disputed legal interests that are

\footnotetext{
24. Id. at Canon $3 \mathrm{~A}(3)$.

25. Id. at Canon $3 \mathrm{~A}(4)$.

26. Model Code OF Judicial CONDUCT Canon 3 (1990).

27. Id. at Canons 3B-E. Of course, states do not always completely follow the ABA proposal. See, e.g., N.C. CODE OF Judicial CONDUCT Canons 3A-3D (2006) (stating that judicial duties encompass adjudicative responsibilities, administrative responsibilities, disqualification, and remittal of disqualification).

28. Model Code of Judicial Conduct Canon 3B(3) (1990).

29. Id. at Canon $3 \mathrm{~B}(4)$.

30. Id. at Canon 3B(7).

31. COdE OF Judicial Conduct Canon 3A(5) (1972).

32. Model Code of Judicial Conduct Canon 3B(8) (1990).

33. CODE OF JUdiCIAL CONDUCT Canon 3A(5) cmt. (1972).

34. Model Code of Judicial Conduct Canon 3B(8) cmt. (1990).
} 
resolved in civil judicial proceedings (such as lienholders, those with subrogation rights, and insurers). ${ }^{35}$

Similarly, the 1972 Code and 1990 Code both generally prohibited ex parte communications between judges and certain persons. ${ }^{36}$ Yet the 1972 Code simply said a judge should "neither initiate nor consider ex parte or other communications concerning a pending or impending proceeding" except as "authorized by law." "37 By contrast, the 1990 Code's standards on ex parte communications specifically authorized certain communications (i.e., for scheduling or administrative purposes) ${ }^{38}$ and authorized separate conferencing, "with the consent of the parties," involving a judge, one party, and that party's lawyer "in an effort to mediate or settle matters pending before the judge." $"$ Thus, in 1990 , there was no recognition of barriers to ex parte conferencing with nonparties who were legally interested in pending civil proceedings (as a result of liens, insurance contracts, or subrogation interests).

As the 1924 Canons evolved into a 1972 Code, and later into the 1990 Code, the judicial role was more particularly and narrowly defined, with an increasing view of adjudicative responsibilities as involving cases and parties rather than pending matters and persons legally interested. The view of the judicial role within the 1990 Code is consistent with Professor Chayes's view of "traditional" civil litigation. ${ }^{40}$

Currently there is discussion about revising the 1990 Code. ${ }^{41}$ But to date there has been little movement away from the perspective that judicial conduct in civil cases involves only "traditional" duties. Under a December 2005 draft, Canon 2 would encompass guidelines on judicial conduct involving the impartial and diligent performance of the duties of a judicial office. ${ }^{42}$ The proposed Canon 2 has guidelines in various

35. Id. An example with an approach similar to the 1972 Code is Canon 3 of the Pennsylvania Code of Judicial Conduct, which speaks of a "full right to be heard" for "every person who is legally interested in a proceeding." PA. CODE OF JUDICIAL CONDUCT Canon 3(a)(4) (2002).

36. See generally Model Code of Judicial Conduct Canon 3B(7) (1990); CodE OF JUDICIAL CONDUCT Canon 3A(4) (1972).

37. CODE OF Judicial CONDUCT Canon 3A(4) (1972).

38. MOdEl CODE OF JUdiCIAL CONDUCT Canon 3B(7)(a) (1990).

39. Id. at Canon $3 \mathrm{~B}(7)(\mathrm{d})$.

40. See Chayes, supra note 5, at 1283 (describing the trial judge as a "neutral arbiter" of interactions among parties).

41. Judicial Code Panel Postpones Final Report for Further Consideration of Difficult Issues, 22 ABA/BNA LAW. MANUAL ON PROF. CONDUCT 193, 193 (2006).

42. Model Code of Judicial Conduct Canon 2 (Final Draft Report Dec. 14, 2005) [hereinafter 2005 Draft], available at $\mathrm{http}: / / \mathrm{www}$.abanet.org/judicialethics/finaldraftreport.html. In April 2006, Commission Chair Mark I. Harrison said he hoped the commission would finish its work and present its proposals to the ABA in February 2007. Judicial Code Panel Postpones Final Report for Further Consideration of Difficult Issues, supra note 41, at 193. 
categories, including adjudication (continuing much of the 1990 Code materials on adjudicative responsibilities, disqualification, and remittal of disqualification) ${ }^{43}$ and administration (containing much of 1990 Code materials on administrative responsibilities). ${ }^{44}$

Within the section on adjudication, the proposed standards of 2005 continue to describe - broadly at times - judicial conduct in civil cases. The standards speak of a duty to "hear and decide matters assigned," "decide all cases with impartiality and fairness"46 (though the accompanying comment states that this duty goes "to all parties"47), to perform diligently all judicial duties, "disposing of all judicial matters promptly and efficiently," 48 and to "accord to every person who has a legal interest in a proceeding ... the right to be heard according to law" 49 (though the accompanying comment on judicial oversight of settlements states that this duty embodies protecting "a party's right to be heard" and repeatedly refers to settlements involving "parties"50). Elsewhere the 2005 proposed standards on adjudication speak more narrowly of the interests of "parties," as in the sections on ex parte communications and disqualification. Thus, one proposed standard declares: "A judge may, with the consent of the parties, confer separately with the parties and their lawyers in an effort to settle matters pending before the judge." Another states: "A judge shall disqualify himself or herself in any proceeding . . . where ... the judge has a personal bias or prejudice concerning a party or a party's lawyer ....,, 52 There are no express bars on separate conferencing with, or bias toward, nonparties who are legally interested. The 2005 proposed amendments to the Model Code of Judicial Conduct continue to focus on "parties" rather than on persons with legal interests and on the pleaded claims rather than on all "matters" in dispute.

The traditional perspective on the role of the trial judge, as described by Professor Chayes, continues in other ABA pronouncements. For

43. 2005 Draft, supra note 42, at Canons 2.05-2.12.

44. Id. at Canons 2.13-2.20. Reporting misconduct provisions (containing much of the 1990 Code materials and disciplinary responsibilities) are located within the section dealing with administration. $I d$. at Canons 2.17-2.18.

45. Id. at Canon 2.05 .

46. Id. at Canon 2.06 .

47. Id. at Canon $2.06 \mathrm{cmt} .3$.

48. Id. at Canon 2.03.

49. Id. at Canon 2.09.

50. Id. at Canon $2.09 \mathrm{cmt} .2$.

51. Id. at Canon 2.10(A)(3).

52. Id. at Canon 2.12(A)(1). 
example, the first Standards Relating to Trial Courts ("1976 Trial Court Standards") were approved by the ABA House of Delegates in February $1976 .{ }^{53}$ Within the commentary accompanying section 2.00 ("Fair and Effective Procedures: General Principle"), there was a discussion of "Supervisory Functions," including work with decedents' estates, juvenile services, and probation services for criminal offenders, ${ }^{54}$ as well as "Other Dispute-Resolving Procedures." were admonished to give "due recognition" both to the "jurisdiction of administrative and quasi-judicial boards and agencies" (requiring "appropriate deference") ${ }^{56}$ and to "the role of arbitration in the resolution of legal controversies," involving active encouragement of "voluntary reference to arbitration." 57 Here, trial courts either provided "a forum for review" or "enforcement" civil case processing. Within section 2.02, on Procedure in Civil Cases, the 1976 Trial Court Standards required "[p]leadings" that reasonably informed "parties" of "claims and defenses," "59 liberal laws on "joinder of claims and parties," 60 and summary treatment of "insufficient" claims and defenses. ${ }^{61}$ The accompanying commentary urged that there be "[p]rocess rules" making it "possible for all appropriate parties to be joined."62

By February 1992, the Trial Court Standards had been altered significantly. ${ }^{63}$ Section 2.00 included discussions of "Supervisory Functions" and, to replace "Other Dispute-Resolving Procedures," discussions of both "Administrative Tribunals," where "appropriate deference" was still required, and "Alternative Dispute Resolution Programs." 64 The latter covered "court-annexed or court-referred" arbitrations as well as mediations and conciliations before nonjudges. ${ }^{65}$ Yet, this part of section 2.00 was limited in application. It referenced only the procedural opportunities for "the parties." Section 2.02 on

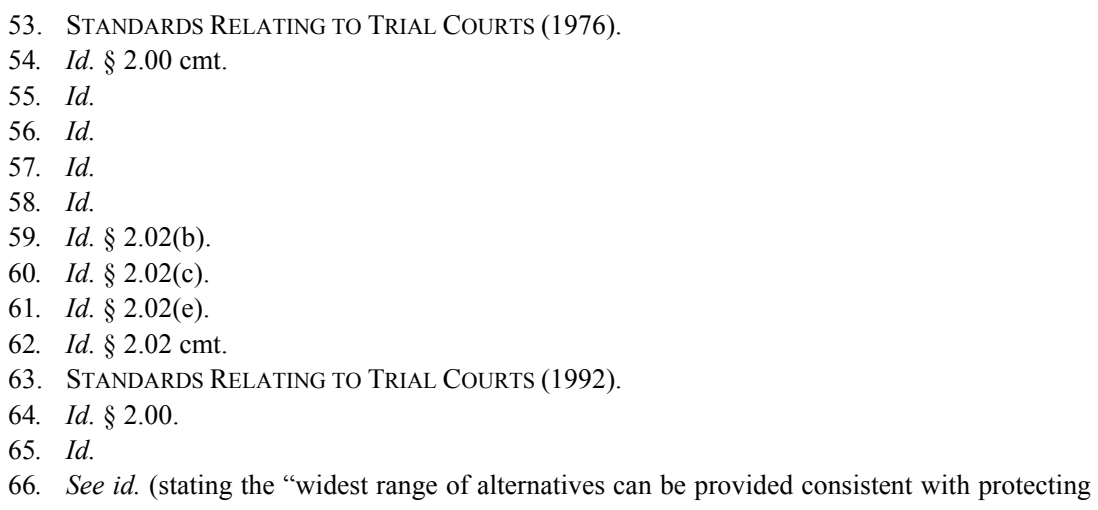


civil case procedure remained substantially unchanged, with provisions directed to "joinder of claims and parties" obtain[ing] reasonable disclosure" of facts and laws at issue. ${ }^{68}$

As with ABA pronouncements, the FRCP, from their implementation in the late 1930s, have also chiefly reflected the vision described by Professor Chayes. Since many states have substantially modeled their written civil procedure laws on the FRCP, the account by Professor Chayes is largely compatible with existing state court rules and statutes on civil case processes. ${ }^{69}$ Under the contemporary FRCP, the adversaries are parties, often represented by lawyers, ${ }^{70}$ who present, or defend against, a "claim for relief"; ${ }^{71}$ who undertake the various methods of formal "discovery"; 72 who make or oppose a "motion" related to a pending claim; ${ }^{73}$ and who undertake pretrial, trial, and post-trial efforts aimed at "claim" resolution. ${ }^{74}$ Further, jurors may only render a "special verdict" on issues "which might properly be made under the pleadings."75 A judgment in a case involving "multiple claims" or "multiple parties" may be limited to the resolution of only a single "claim," whether presented in a "claim, counterclaim, cross-claim, or third-party claim." "76 Further, an offer of judgment often may only be made by "a party defending against a claim." 77 So, like ABA principles, the FRCP and state civil procedure laws speak mostly to parties with their claims, rather than to the broader group of persons who are "legally interested" or to the broader range of disputes that are possibly subject to resolution with judicial assistance.

The United States Judicial Code, embodying congressional directives that structure and guide the Article III judiciary of the federal government, similarly speaks to parties and their claims rather than to all persons with legal interests in dispute resolution. For example, claims

the rights of the parties," and noting the "opportunity for the parties to choose an ADR professional").

67. Id.

68. Id.

69. But see John B. Oakley, A Fresh Look at the Federal Rules in State Courts, 3 NEV. L.J. 354,355 (2002/2003) ("Federal procedure is less influential in state courts today than at anytime in the past quarter-century.").

70. FED. R. CIV. P. 11(a).

71. FED. R. CIV. P. 8(a)-(b).

72. See, e.g., FED. R. CIV. P. 26 (stating the general provisions governing discovery).

73. FED. R. CIV. P. 7, 11.

74. See, e.g., FED. R. CIV. P. 56(a)-(b) (discussing summary judgment for claimant or defendant); see also FED. R. CIV. P. 59(a) (discussing grounds for a new trial).

75. FED. R. CIV. P. 49(a).

76. FED. R. CIV. P. 54(b).

77. FED. R. CIV. P. 68. 
are at the core of the supplemental jurisdiction statute, a law that describes only some of the federal courts' adjudicatory authority over disputes that are factually related to pending diversity or federal question claims. $^{78}$ Pendent and ancillary adjudicatory authority under federal precedents are broader than the statutory supplemental authority as they may not involve the named parties at all. Additionally, the convenience of the parties, rather than of all those who are legally interested, is at the core of the change of venue statute. However, there is a reference to considerations of what "justice" demands. ${ }^{79}$

The Chayes/ABA/FRCP vision of trial court adjudicatory authority, emphasizing named parties and their claims rather than all those who are legally interested in the event(s) prompting the presentation of those claims, dominates the teaching of civil procedure in American law schools, usually in the first year. For example, Professor Yeazell's very popular civil procedure book begins with "a simple and plausible fact situation" involving a college student from Michigan who, while visiting his parents in Illinois, gets into a car accident with a lifelong Illinois resident. $^{80}$ The fact pattern is developed in the first chapter to introduce subjects such as jurisdiction, ${ }^{81}$ venue,${ }^{82}$ pleading and motion practice, ${ }^{83}$ joinder (where the student had a passenger, there was a third car involved, or there was shoddy work done by a mechanic) ${ }^{84}$ discovery, ${ }^{85}$ summary judgment, ${ }^{86}$ trial, ${ }^{87}$ appeals, ${ }^{88}$ and preclusion. ${ }^{89}$ Insurance is only mentioned in an illustrative case, where an insurer files a lawsuit seeking to recover what it paid to its insured for the damage caused by the defendant. ${ }^{90}$ There is no talk of insurers as lienholders, of insurers as nonparties who are nevertheless on the hook for judgments against their insureds, or of insurance policy coverage issues. There is no talk of other lienholders, likely including the plaintiff's very own attorney. Early on in Professors Friedenthal, Miller, Sexton, and Hershkoff's civil

78. See 28 U.S.C. $\S 1367$ (a) (2000) (speaking to jurisdiction over "all other claims"); id. § 1367 (c) (guiding a district court on its discretion to decline jurisdiction "over a claim").

79. 28 U.S.C. $\S 1404$ (a) (2000).

80. Steven C. Yeazell, Civil Procedure 2 (6th ed. 2004)

81. Id. at $4-11$.

82. Id. at 11 .

83. Id. at $12-23$.

84. Id. at $24-27$.

85. Id. at $28-34$.

86. Id. at $34-39$.

87. Id. at $39-45$.

88. Id. at $51-55$.

89. Id. at $45-53$.

90. Id. at 46-50. The illustrative case is Rush v. City of Maple Heights, 147 N.E.2d 599 (1958). 
procedure book, there is comparably "a relatively uncluttered hypothetical case" involving a car accident wherein a pedestrian sues the employer of the driver who caused the injuries. ${ }^{91}$ Again, little is said about lienholders, including attorneys, medical providers, and insurers, or about insurers of the named defendants.

\section{NEW CIVIL CASE RESPONSIBILITIES: FEWER TRIALS, MoRE THAN PleAdED Claims, MoRe Judicially MaNAGED SETTLEMENTS, AND MORE APPEALS}

ABA standards and federal and state contemporary civil procedure laws continue to speak only to parties, rather than to the broader array of legally interested persons, and to claims, rather than to all "matters" that may be resolved in private civil cases. Yet trial courts increasingly face far fewer trials in certain types of private disputes; help resolve more claims than those pleaded; initiate more settlement talks that occur beyond court-directed outside arbitrations, mediations, or conciliations; and hear more appeals. Unfortunately, these trial court responsibilities remain substantially unrecognized or unguided in the ABA standards or in written American civil procedure laws.

\section{A. Fewer Trials}

There are fewer trials for certain private civil claims today, such as consumer and civil rights in employment, because of the expansive readings of the Federal Arbitration $\mathrm{Act}^{92}$ by the Supreme Court of the United States, ${ }^{93}$ as well as the related explosion in the numbers of compulsory and binding arbitration contracts covering future civil disputes. $^{94}$ The FAA generally declares that "a contract evidencing a transaction involving commerce to settle by arbitration a controversy thereafter arising out of such contract . . . shall be valid, irrevocable, and enforceable, save upon such grounds as exist at law or in equity for the revocation of any contract." 95 In Allied-Bruce Terminix Companies v.

91. Jack H. Friedenthal, Arthur R. Miller, John E. SeXton \& Helen Hershkoff, CiviL Procedure 5 (9th ed. 2005); see also AlLAN IDES \& Christopher N. MAY, Civil Procedure: CASES AND PROBlems 8-19 (2d ed. 2006) (presenting a typical hypothetical case involving a bicycle accident).

92. 9 U.S.C. $\S \S 1-14(2000)$.

93. See infra notes 96-102 and accompanying text (discussing two such cases).

94. See infra notes 103-04 and accompanying text (citing several articles on this topic).

95. 9 U.S.C. $\$ 2$. 
Dobson, ${ }^{96}$ in 1995, the Supreme Court reaffirmed that the Act, grounded on Commerce Clause powers, preempts state antiarbitration laws and applies in state courts. ${ }^{97}$ The Court also broadened the Act so as to cover not only contracts contemplating substantial interstate activity, but also contracts that, in fact, only turned out to involve some interstate commerce. ${ }^{98}$ The Act exempts "contracts of employment of seamen, railroad employees, or any other class of workers engaged in foreign or interstate commerce." City Stores, Inc. v. Adams, ${ }^{100}$ limited the exemption to contracts of employees whose work clearly contemplated interstate commerce, such as transportation workers. ${ }^{101}$ Thus, the Act applies to employees whose actual work involves some degree of interstate commerce. ${ }^{102}$

As a result of these and other Supreme Court decisions, there has been an explosion in the number of enforceable contracts mandating arbitration of future civil claims. There is no indication that this escalation will end anytime soon. If anything, it seems the biggest bangs are yet to be heard. These contractual arbitrations occur outside of American trial courts, precluding traditional trials. Thus, for many disputes arising out of consumer purchases ${ }^{103}$ or private employment, ${ }^{104}$ there are far fewer possible trials today than in the prearbitration era.

There is also much evidence that, even for civil claims that continue to be filed and resolved in American trial courts regularly, there are

96. 513 U.S. 265 (1995).

97. Id. at 272,275 .

98. Id. at 277 .

99. 9 U.S.C. $\$ 1$.

100. 532 U.S. 105 (2001).

101. Id. at 121. The Court based its decision on the rationale that the phrase "'engaged in commerce' is narrower than the more open-ended formulations 'affecting commerce' or 'involving commerce." Id. at 118 .

102. See id. at 121 ("It would be rational for Congress to ensure that workers in general would be covered by the provisions of the FAA, while reserving for itself more specific legislation for those engaged in transportation.").

103. For a review and critique of the burgeoning private compelled and binding arbitrations involving consumer purchases, see, for example, Christopher R. Drahozal, "Unfair" Arbitration Clauses, 2001 U. ILL. L. REV. 695, 698 (2001), which uses empirical methods to analyze predispute arbitration pacts in consumer agreements, and Jean R. Sternlight, Creeping Mandatory Arbitration: Is It "Just?", 57 STAN. L. REV. 1631, 1635 (2005), which argues that "mandatory arbitration is problematic for two fundamental reasons: lack of consent and lack of public scrutiny."

104. For a review and critique of the burgeoning compelled and binding private arbitrations involving private employment disputes, see, for example, Cynthia Estlund, Rebuilding the Law of the Workplace in an Era of Self-Regulation, 105 COLUM. L. REV. 319, 324-25 (2005), which suggests the use of monitored self-regulation, with monitors who are independent of employers and accountable to employees and the public. 
fewer trials. ${ }^{105}$ Whatever the reasons for the decreasing number of civil jury trials, ${ }^{106}$ written civil procedure laws chiefly premised on a "jurybased legal culture" are grounded on "legend" rather than on the "reality" of contemporary civil litigation. ${ }^{107}$

\section{B. More than Pleaded Claims}

There is also increasing trial court authority over legal issues, including claims, that are factually related to pending private civil actions, but that do not involve any of the expressly named parties. For example, in civil litigation today, two insurers of two opposing parties may be at odds and may be the real adversaries. Furthermore, a plaintiff's attorney, via a contingency fee agreement, or a plaintiff's creditor, via a lien, are more likely to assert a property interest in the proceeds of any monetary recovery by the plaintiff than they were fifty years ago. ${ }^{108}$ Increased federal district court authority over disputes

105. See, e.g., Murray, supra note 3, at 53 (reviewing the numbers of civil jury verdicts in Massachusetts state trial courts from 1925 to 2003 and reporting there were 3022 civil jury verdicts in 1925 and 586 in 2003); Judith Resnik, Procedure as Contract, 80 Notre Dame L. ReV. 593, 616-17 (2005) ("In the early 1940s, about fifteen percent of federal civil cases ended with a trial. In 1962, [this was] about twelve percent . . .; today, trials are begun in about two percent of the civil docket. ... [E]ven the absolute number of civil trials has decreased, from about 5800 in 1982 to about 4600 in 2002." (citations omitted)). See generally Marc Galanter, The Vanishing Trial: An Examination of Trials and Related Matters in Federal and State Courts, 1 J. EMPIRICAL LEGAL STUD. 459, 459 (2004) (reviewing data compiled by the Administrative Office of the United States Courts on federal district courts for 1962 to 2002). The reasons for the decline are disputed. See, e.g., Stephen B. Burbank, Keeping Our Ambition Under Control: The Limits of Data and Inference in Searching for the Causes and Consequences of Vanishing Trials in Federal Court, 1 J. EMPIRICAL LEGAL STUD. 571, 571 (2004) (reflecting on Galanter's work and arguing that "Galanter may underestimate the influence of both changing demand for court services ... and of changing demand of judicial services on the trial rate").

106. See Murray, supra note 3, at 58-59 (suggesting, inter alia, increased use of summary judgment and alternative dispute resolution mechanisms, as well as the expense and unpredictability of jury verdicts).

107. Professor Murray observes:

Most of the members of the current generation of mature American lawyers and judges received their legal education ... in a culture in which the jury trial was at the core....

Fifty or more years ago, this jury-based legal culture had some real connection with reality. A fair proportion of the lawyers and many of the judges were actually involved in civil jury trials on a regular basis. ...

The current statistics make it clear that by comparison with previous generations, lawyers and judges of today are living [in] a legal culture in which trial by jury is more a legend than a reality .... The trend ... strongly suggests that the role of the civil jury trial in our legal culture today is based on a past, rather than a present, reality. Id. at 60 .

108. See, e.g., Samuel A. Perroni \& Mona J. McNutt, Criminal Contingency Fee Arrangements: How Fair Are They?, 16 U. ARK. LiTTLE ROCK L.J. 211, 241 (noting that in the 1980s lawyers began "utilizing contingency fee agreements more frequently and more innovatively"). But see Marc 
involving nonparties was expressly recognized by the Supreme Court in 1994 in Kokkonen v. Guardian Life Insurance Co. of America. ${ }^{109}$ The Court declared that in the absence of a statutory basis, a federal district court could exercise

ancillary jurisdiction ... for two separate, though sometimes related, purposes: (1) to permit disposition by a single court of claims that are, in varying respects and degrees, factually interdependent . . and (2) to enable a court to function successfully, that is, to manage its proceedings, vindicate its authority and effectuate its decrees. ${ }^{1}$

The aforementioned general statute on supplemental jurisdiction only partially addresses federal subject matter jurisdiction over factually interdependent nonparty claims. ${ }^{111}$ It seemingly permits jurisdiction both over claims between parties and over nonparty claims, as it authorizes "supplemental jurisdiction over all other claims that are so related to claims" already presented under diversity or federal question original jurisdiction "that they form part of the same case or controversy." 112 The federal statute does not expressly demand that all supplemental claims that were heard or otherwise resolved could have been joined, pleaded, or otherwise formally presented. ${ }^{113}$ Little else is said of nonparties in the supplemental jurisdiction statute. For example, it does not recognize Supreme Court precedent indicating that the ancillary adjudicatory authority, always discretionary in nature, operates differently for related nonparty claims than for related claims between parties. ${ }^{114}$ The Court has said that ancillary authority over factually interdependent claims is less available when the claims involve "parties not named in any claim that is independently cognizable by the federal court," as such claims are "fundamentally different" than claims involving named parties. ${ }^{115}$ Beyond the necessary relatedness, the Court has also said that federal adjudicatory authority over nonparty claims requires "an examination of the posture" in which the claims were asserted and the "specific statute that confers [original] jurisdiction over" the pleaded claims involving the

Galanter, Anyone Can Fall Down a Manhole: The Contingency Fee and Its Discontents, 47 DEPAUL L. REV. 457, 474 (1998) (acknowledging hints of decline in contingency fee use).

109. 511 U.S. 375 (1994).

110. Id. at 379-80 (citations omitted).

111. 28 U.S.C. $\S 1367$ (a) (2000).

112. Id.

113. Id.

114. Id.

115. Finley v. United States, 490 U.S. 545, 549 (1989), superseded by statute, 28 U.S.C. § 1367(a) (2000), as recognized in Exxon Mobile Corp. v. Allapattah Servs., Inc., 125 S. Ct. 2611, 2613 (2005). 
parties. ${ }^{116}$ The supplemental jurisdiction statute is too silent on trial court adjudicatory authority involving nonparties. ${ }^{117}$ In state civil procedure rules and statutes, ${ }^{118}$ as well, the roles played in civil litigation by "legally interested" nonparties often remain unscripted. ${ }^{119}$

Nonparty claims often involve insurers. ${ }^{120}$ "At times, the insurers, as nonparties, seek judicial remedies from [their insureds who are] parties, as when they place liens on the proceeds of any judgments or out-ofcourt settlements [the insureds] may obtain as [party] claimants." ${ }^{, 121}$ Remedies may even be pursued at times by nonparty insurers against other nonparty insurers (i.e., where both parties are insured). ${ }^{122}$ Thus, "nonparty insurers of plaintiffs may seek to resolve [disputes] against nonparty insurers of defendants that are related to the pending claims

116. Id. at 551 (citing Owen Equip. \& Erection Co. v. Kroger, 437 U.S. 365, 373 (1978)).

117. Jeffrey A. Parness \& Daniel J. Sennott, Expanded Recognition in Written Laws of Ancillary Federal Court Powers: Supplementing the Supplemental Jurisdiction Statute, 64 U. PITT. L. REV. 303, 304-05 (2003) (suggesting the elimination of uncertainty and confusion through statutory amendments reflecting the Kokkonen analysis); see also Myers v. Richland County, 429 F.3d 740, 747, 749-50 (8th Cir. 2005) (stating that ancillary enforcement jurisdiction, while a "viable doctrine," was not codified in the supplemental jurisdiction statute; enforcement authority is recognized in a new lawsuit in the same court brought by a third-party beneficiary to a settlement in an earlier lawsuit wherein enforcement jurisdiction was expressly retained).

118. Many state trial courts are unlike federal district courts in that they are constitutionally established general jurisdiction courts. For example, in Illinois circuit courts have "original jurisdiction of all justiciable matters." ILL. CONST. art. VI, § 9. Because of this, a Kokkonen-type analysis often develops wholly without statute or through court rules. The analysis may develop without statute through, for example, judicial precedents, as in Paulucci v. General Dynamics Corp., 842 So. 2d 797, 801-03 (Fla. 2003), employing an "inherent power" analysis regarding same-case enforcement of a settlement approved by the trial court. It may develop through court rules, as in TEX. R. CIV. P. 11, which requires agreements between parties or attorneys regarding pending suits to be in writing. Unlike congressional authority over federal district court jurisdiction, authorized by U.S. CONST. art. III, § 1, which states "[t]he judicial Power of the United States, shall be vested in . . . such inferior Courts as the Congress may from time to time ordain and establish, similar state legislative authority over the establishment and over what is heard by state general jurisdiction trial courts can be precluded by the judicial article of the state constitution. See, e.g., FLA. Const. art. V, $\S 1$ ("The judicial power shall be vested in a supreme court, district courts of appeal, circuit courts and county courts. No other courts may be established by the state ...."). State high court cases seeking guidance from Kokkonen include Hanson v. Board of Education, 479 S.E.2d 305, 309 (W. Va. 1996) and Amantiad v. Odum, 977 P.2d 160, 167-68 (Haw. 1999).

119. But see, e.g., МiсH. Ст. R. 5.125(C)(6) (stating that in a proceeding for an examination of an account of a fiduciary, notice must be given to "interested persons," who include "insurers and sureties who might be subject to financial obligations as the result of the approval of the account").

120. See Jeffrey A. Parness \& Tait J. Lundgren, Nonparty Insurers in Federal Civil Actions: The Need for New Written Civil Procedure Laws, 36 CREIGHTON L. REv. 191, 196 (2003) ("Nonparty claims adjudicated in federal civil actions often involve insurers.").

121. Id. at 196-97.

122. See id. at 197 ("Conceivably, similar remedies may even be pursued by nonparty insurers against other nonparties ...."). 
between the plaintiffs and defendants" $" 123$ (e.g., disputes regarding insurance coverage).

\section{More Judicially Managed Settlements}

In American trial courts today, there are also more judicially managed settlement talks involving private civil disputes. Consider the evolution of FRCP 16 since its appearance in 1938. ${ }^{124}$ As with other FRCP, this federal rule is followed in many states. ${ }^{125}$ Initially, FRCP 16 was entitled "Pre-Trial Procedure; Formulating Issues." explicit mention of settlement; rather, it addressed trial preparation conferences regarding simplifying issues, amending pleadings, avoiding unnecessary proof, limiting experts, and referring to factual issue matters. ${ }^{127}$

FRCP 16 was considerably amended in $1983 .{ }^{128}$ The title changed to "Pretrial Conferences; Scheduling; Management." "129 It required early scheduling and planning conferences for many civil cases and anticipated multiple conferences before trial. ${ }^{130}$ It broadened judicial authority to reach unrepresented parties as well as attorneys. ${ }^{131}$ "Facilitating the settlement of the case" became a valid objective of pretrial conferences. ${ }^{132}$ The new rule suggested "the possibility of settlement" as a subject for discussion at pretrial conferences. ${ }^{133}$ It did not list possible participants in conferences. ${ }^{134}$ However, it stated that "at least one of the attorneys for each party participating in any conference before trial shall

123. Id.

124. The changes in the pretrial conference work of federal district judges in civil cases since 1938 are reviewed in Judith Resnik, Managerial Judges, 96 HARV. L. REV. 374, 374-432 (1982). There have been no comparable changes in criminal case responsibilities where settlement facilitation remains, for the most part, with the parties. See, e.g., FED. R. CRIM. P. 11(c)(1) (stating "[t]he court must not participate in . . . discussions" relating to a plea agreement); ILL. SUP. CT. R. 402(d)(1) ("The trial judge shall not initiate plea discussions.").

125. See Jeffrey A. Parness \& Matthew R. Walker, Thinking Outside the Civil Case Box: Reformulating Pretrial Conference Laws, 50 U. KAN. L. REV. 347, 349-53 (2002) (reviewing contemporary state court practices under 1938, 1983, and 1993 versions of FED. R. CIV. P. 16).

126. FED. R. CIV. P. 16, 308 U.S. 645, 684 (1938) (amended 1983, 1987, and 1993).

127. Parness \& Walker, supra note 125, at 350-53 (citing FED. R. Civ. P. 16, 308 U.S. at 684).

128. Id. at 350 .

129. FED. R. CIV. P. 16, 97 F.R.D. 165, 201 (1983); Parness \& Walker, supra note 125, at 350 (citing the 1983 version of FED. R. CIV. P. 16).

130. Parness \& Walker, supra note 125, at 350 (citing FED. R. CIV. P. 16, 97 F.R.D. at 201-05)

131. Id. (citing FED. R. CIV. P. 16(a), 97 F.R.D. at 201).

132. Id. (citing FED. R. CIV. P. 16(a)(5), 97 F.R.D. at 201).

133. Id. (citing FED. R. CIV. P. 16(c), 97 F.R.D. at 203).

134. Id. 
have authority to enter into stipulations and to make admissions regarding all matters that the participants may reasonably anticipate may be discussed." ${ }^{\prime 35}$ This suggests that the rule limits participants to parties and/or their attorneys. ${ }^{136}$

The Advisory Committee noted that FRCP 16 was a success partly due to improvement and expansion of the settlement process. ${ }^{137}$ It stated that pretrial conferences for the sole purpose of settlement could be desirable and that "settlement should be facilitated at as early a stage of the litigation as possible." 138 However, it noted that a mandatory settlement conference "would be a waste of time in many cases."139

The most recent amendment to FRCP 16 occurred in $1993 .{ }^{140}$ The 1993 changes merely refined the previous rule. ${ }^{141}$ It suggests judges be more active in the pretrial conferences. ${ }^{142}$ As opposed to the 1983 version offering "the possibility of settlement" as a possible subject for pretrial conference, the 1993 version advises the court may "take appropriate actions" regarding settlement. ${ }^{143}$ Under the 1993 Rule, judges may "require that a party or its representative be present or reasonably available by telephone in order to consider possible settlement of the dispute." ${ }^{144}$

\section{More Appeals}

American trial courts today undertake far more review of decisions on civil claims made elsewhere. This increase seemingly resulted from expanding use of administrative tribunals and other governmental dispute resolution bodies to resolve initially private civil disputes. As well, there have been increasing numbers of civil claims arbitrated under federal and

\footnotetext{
135. Id. (citing FED. R. CIV. P. 16(c), 97 F.R.D. at 204).

136. Id.

137. Id. at 351 .

138. Id. (citing FED. R. CIV. P. 16 advisory committee's note, 97 F.R.D. at 210).

139. Id. (citing FED. R. CIV. P. 16 advisory committee's note, 97 F.R.D. at 210).

140. FED. R. CIV. P. 16, 146 F.R.D. 401, 597-601 (1993); Parness \& Walker, supra note 125, at 351 (citing the 1993 version of Rule 16).

141. Parness \& Walker, supra note 125 , at 351.

142. Id.

143. Id. (citing FED. R. CIV. P. 16(c), 146 F.R.D. at 600).

144. Id. (citing FED. R. CIV. P. 16(c)(14), 146 F.R.D. at 601). Since 1993 the rule has attracted critics. For example, Professor Judith Resnik laments: "In the contemporary rule, we find the managerial judge, the settlement judge, the dealmaking judge, the judge promoting alternative dispute resolution, and thus the Los Angeles judge telling lawyers that to go to trial was to admit failure of this (new) system." Judith Resnik, Trial as Error, Jurisdiction as Injury: Transforming the Meaning of Article III, 113 HARV. L. REV. 924, 937 (2000).
} 
state acts that require trial courts perform the appellate, or quasiappellate, process of confirmation, allowing the courts to then enforce arbitration awards.

The expanding use of administrative tribunals to resolve private civil claims in the first instance has been legislatively mandated. However, the delegation doctrine limits legislators. It requires certain core governmental responsibilities be left to only one of the three governmental branches set out constitutionally. ${ }^{145}$ This means that there may be some essential judicial functions regarding civil case resolutions. ${ }^{146}$ The jury trial right also limits legislators. ${ }^{147}$ It demands that only incidental private interests be adjudicated administratively when reasonably necessary to effectuate an administrative agency's primary regulatory purpose. ${ }^{148}$ Otherwise, American legislators ordinarily have leeway in directing certain private claims to agencies, albeit with later appellate-type court review. Constitutionally, many state trial courts are simply recognized as having the authority to exercise whatever appellate jurisdiction may be provided by law. In Florida, the constitution is more explicit, declaring that the circuit courts "shall have the power of direct review of administrative action prescribed by general law." Increasingly, trial court review of agency adjudications is contemplated by legislatures and guided by procedures found in both a general administrative procedure act, governing judicial review of determinations from a variety of administrative agencies, ${ }^{150}$ and in

145. See, e.g., Mistretta v. United States, 488 U.S. 361, 361 (1989) (holding that sentencing guidelines are constitutional); McHugh v. Santa Monica Rent Control Bd., 777 P.2d 91, 93 (Cal. 1989) (holding unconstitutional administrative remedies provision of city's rent control law).

146. Mistretta, 488 U.S. at 386 (recognizing certain governmental functions may be "exclusively committed" to one branch of government); McHugh, 777 P.2d at 108 (courts must vigilantly apply the "principle of check" in order to preserve for the courts the "true" judicial power). In the civil case arena, a core judicial function is often described as involving the resolution of contested facts in a private civil dispute that leads to "an award of unliquidated common law damages for personal injuries.” Broward County v. La Rosa, 505 So. 2d 422, 423-24 (Fla. 1987); see also Walnut Creek Manor v. Fair Employment \& Hous. Comm'n, 814 P.2d 704, 713 (Cal. 1991) (citing Broward County, 505 So. $2 \mathrm{~d}$ at $423-24$ ).

147. See, e.g., Granfinanciera S.A. v. Nordberg, 492 U.S. 33, 33 (1989) (stating Colombian Government was not entitled to a jury trial). As well, state legislatures are occasionally limited by state constitutional rights to remedy/open courts provisions. See, e.g., Gordon L. Roberts \& Sharrieff Shah, What is Left of Berry v. Beech-The Utah Open Courts Jurisprudence?, 2005 UTAH L. REV. 677, 679 (stating there are two ways open courts provisions are read: (1) as procedural, and (2) as substantive wherein the legislatures' ability to control extant remedies is limited).

148. Granfinanciera, 492 U.S. at $55 \mathrm{n} .10$ (stating that Congress may decline the right to a jury trial when the rights at issue are "statutory rights that are integral parts of a public regulatory scheme"); see also McHugh, 777 P.2d at 108 (using incidental private rights analysis for separation of powers issue).

149. Fla. CONST. art. V, § 5 (b).

150. See, e.g., Federal Administrative Procedure Act, 5 U.S.C. $\S 551-59$ (2000); Illinois 
special provisions within enabling legislation outlining special judicial review powers relevant to a particular agency. ${ }^{151}$

Besides agency decisions, American trial courts undertake more appellate-type proceedings today as they review and confirm the increasing numbers of arbitration awards under the FAA ${ }^{152}$ and related state arbitration acts. The FAA and similar state acts expressly recognize a reviewing role for trial courts regarding arbitration awards arising from disputes governed by compulsory and binding arbitration pacts. The federal act states that federal district courts should normally confirm such arbitration awards. There is some wiggle room, though far less than with traditional appellate court review of trial court decisions where there are usually de novo (legal questions), clearly erroneous (factual questions), and abuse of discretion standards of review. The FAA only allows a trial court to vacate, modify, or correct an arbitration award for very limited reasons, such as "corruption, fraud, or undue means" in the procurement of the award; "evident partiality or corruption" in any arbitrator; or "an evident material mistake."153 Beyond these grounds, arbitration awards will be confirmed unless they direct parties to violate the law. Thus, as the Seventh Circuit Court of Appeals said in IDS Life Insurance Co. v. Royal Alliance Associates, ${ }^{154}$ "neither error nor clear error nor even gross error is a ground for vacating an award." 155 In that case, the court confirmed an arbitration award simply because it was satisfied that the arbitrators had resolved the entire dispute and their resolution could be figured out, even though their resolution was largely "incomprehensible."

\section{NEW VISIONS AND NEW GUIDELINES FOR THE GENERAL JURISDICTION TRIAL COURTS}

The new visions of trial courts should prompt changes in written civil procedure, professional responsibility, and even certain substantive laws. Laws grounded solely or primarily on Professor Chayes's narrow vision of civil trial courts hearing private-rights cases are inadequate. Unfortunately, necessary changes have been slow, resulting in much

Adminstrative Review Law, 735 ILl. COMP. STAT. ANN. 5/3-101 to -113 (West 2003).

151. See, e.g., 42 U.S.C. $\S 610$ (c) (2000) (stating a state appealing adverse action on certain block grants has ninety days to seek district court review).

152. Federal Arbitration Act, 9 U.S.C. $\S \S 1-307$ (2000).

153. Id. $\S \S 10-11$.

154. 266 F.3d 645 (7th Cir. 2001).

155. Id. at 650 .

156. Id. at 648 
confusion and widely differing approaches to common legal issues, even within a single multijudge court. The confusion over judicial settlement conferences, settlement talks personally presided over by trial court judges, is illustrative. The divergent judicial approaches, prompted by underinclusively written laws with little legislative history, demonstrate the dangers of written rules and statutes that expressly reflect, at best, only Professor Chayes's vision of trial court work. ${ }^{157}$

The confusion over the calls for increased judicial settlement conferencing is exemplified in one federal appellate court ruling addressing whether district judges can compel the attendance of nonparties, such as insurers. ${ }^{158}$ The ruling has significant practical import as nonparties often hold the keys to amicable and complete civil case resolutions. This confusion would be more easily mitigated upon revision of civil trial courts. With a new perspective, new guidelines on judicial settlement conferences could be more readily implemented.

\section{A. Narrow Vision, Resulting Confusion}

In 1989, in G. Heileman Brewing Co. v. Joseph Oat Corp., ${ }^{159}$ a majority of the Seventh Circuit went beyond the wording of the 1983 version of FRCP 16 in an attempt to facilitate a just, speedy, and inexpensive resolution of a pending civil case. ${ }^{160} \mathrm{~A}$ federal magistrate

157. See, for example, Slansky \& Yeazell, supra note 12, at 701, where the authors observe:

Civil settlements are an arena of great entrepreneurial creativity, welcomed by the rules and actively encouraged from the bench. Encouragement, in fact, is typically the judge's sole role in civil settlement. The rules have nothing to say about the content of civil settlements, and neither, in the vast majority of cases, does the judge presiding over the litigation. The terms of a civil settlement need bear no relation to the outcome dictated by substantive law. Nor need they bear any resemblance to the settlement of a nearly identical case being handled in the courtroom next door. The dark side of unconstrained creativity is arbitrary lawlessness.

158. There are significant differences among trial court judges on other judicial settlement conferencing issues. See, e.g., Galanter \& Cahill, supra note 1, at 1342-43 (discussing a 1980 nationwide survey of federal and state trial judges showing that $68 \%$ intervened "subtly" in judicial settlement conferences, $10 \%$ intervened "aggressively," and $22 \%$ were "noninterventionist"). Another survey showed that $41 \%$ of federal judges and $56 \%$ of state judges reported they had "suggested settlement terms," though far fewer judges were interventionist in bench trials than in jury trials. Id. at 1343 .

159. 871 F.2d 648 ( 7 th Cir. 1989) (en banc). This is not an isolated incident of widely divergent views on trial court authority to compel a nonparty's attendance at a settlement, or settlementfacilitating, proceedings, be it before the trial judge or another (e.g., mediator, arbitrator, conciliator). Similar views are shown in the notes as the Heileman opinions are described.

160. Id. at 652-53. On occasion, courts do not explore the language of the pertinent pretrial conference rule and simply recognize compulsory powers over interested nonparties. See, e.g., In re LaMarre, 494 F.2d 753, 756 (6th Cir. 1974) (finding that court had power to compel an insurance company's appearance because it was liable for any damages owed by the defendant). 
judge had ordered a defendant's "corporate representative with authority to settle" to attend a pretrial settlement conference. ${ }^{161}$ The only defendant's representative who appeared was its attorney. ${ }^{162}$ The trial court determined the order was violated and imposed sanctions under FRCP 16(f). ${ }^{163}$ The defendant argued on appeal, to no avail, that the contemporary version of FRCP 16 permitted the trial court to order the attendance of "attorneys for the parties or any unrepresented parties." 164

Writing for the majority, Judge Kanne found that FRCP 16 did not "completely describe and limit the power of the federal courts," though the "concept that district courts exercise procedural authority outside the explicit language of the rules of civil procedure is not frequently documented." $165 \mathrm{He}$ reasoned that "the mere absence of language in the federal rules ... should not, and does not, give rise to a negative implication of prohibition."166 Written civil procedure laws only "form and shape certain aspects of a court's inherent powers," he said, and do not bar the continued exercise of those powers "where discretion should be available."167 Judge Kanne concluded that FRCP 16 did not restrict district judges in the conduct of pretrial conferences, as written laws do not limit, but in fact are "enhanced by," inherent judicial power. ${ }^{168}$

While Judge Kanne found that inherent judicial power enhanced FRCP 16, the dissenters in Heileman found the use of such power inappropriate, at least in the pending case. ${ }^{169}$ Some dissenters found that any inherent power should not encompass mandated attendance by a represented party, its agent, or any others not mentioned in the rule. ${ }^{170}$

In dissent, Judge Posner explained that under the written federal rule, the "main purpose of the pretrial conference is to get ready for trial."171 Accordingly, a represented party's presence at a pretrial conference would only be needed to facilitate settlement. ${ }^{172}$ Judge Posner then discussed the dangers of an overly broad interpretation of an inherent

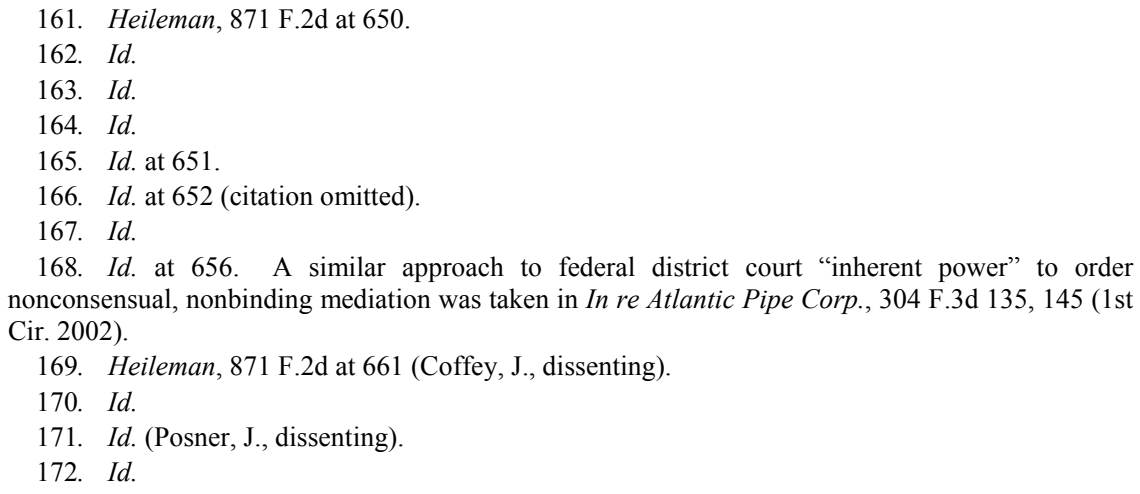


power to promote settlement. ${ }^{173}$ One danger involved encouraging "judicial high-handedness" because of the idea that "power corrupts."174 Also, because people hire attorneys to "economize on their own investment of time in resolving disputes," there was a danger in overriding their judgment. ${ }^{175}$ However, Judge Posner also recognized that because "necessity breaks iron," inherent authority is "a potentially useful tool for effecting settlement, even if there is some difficulty in finding a legal basis." 176 He recognized that trial judges face "heavy" workloads and was hesitant "to infer inadvertent prohibitions" by federal rulemakers of the powers that are necessary for the trial judges to function successfully. ${ }^{177} \mathrm{He}$ did not further explore the contours of FRCP 16 as he found that, whatever it-or any inherent powerpermitted, the order against Joseph Oat was impermissible because Oat had made it clear that it would not agree to pay any money. ${ }^{178}$

In his dissent, Judge Coffey was even more cautious about inherent power. He was "convinced that Rule 16 does not authorize a trial judge to require a represented party litigant to attend a pretrial conference together with his or her attorney because the rule mandates in clear and unambiguous terms that only an unrepresented party litigant and attorneys may be ordered to appear." "179 While Judge Coffey agreed that judges do possess some degree of inherent authority, he believed "this authority is limited," suggesting that more expansive trial court powers should be granted through federal judicial rulemaking. ${ }^{180}$ He outlined a "host of problems" that accompany an overly broad inherent power doctrine, including "a substantial invitation for judicial abuse" as well as the prospect of undermining the appearance of impartiality and causing

173. Id

174. Id.; see also In re NLO, Inc., 5 F.3d 154, 157-58 (6th Cir. 1993) (using this rationale to overturn a trial court order mandating participation in a summary jury trial, noting that the FRCP did not expressly permit it and proposals to expand trial court compulsory powers involving summary trials had been expressly rejected).

175. See Heileman, 871 F.3d at 657 (Posner, J., dissenting) (stating judges may "ignore the value of other people's time" in their zeal to settle cases).

176. Id.

177. $I d$.

178. Id. at 658 (discussing the lack of duty imposed by Rule 16 to engage in good faith bargaining and Joseph Oat's refusal to accept monetary settlement). But cf. Pitman v. Brinker Int'l, Inc., 216 F.R.D. 481, 486 (D. Ariz. 2003) (suggesting that even those who profess to be uninterested in settling can have their physical presence compelled because in "the give-and-take" of settlement talks, views of a case can be "altered").

179. Heileman, 871 F.2d at 658 (Coffey, J., dissenting).

180. See id. at 658,663 ("[I]f we wish to grant federal trial judges the power, let it be accomplished through the accepted channels of the Supreme Court."). 
confusion and dismay among litigants over judicial participation. ${ }^{181}$ Finally, he said the majority opinion "upsets the delicate balance the Supreme Court and Congress struck between the needs for judicial efficiency and the rights of the individual litigant." 182

Judge Ripple, in dissent, found "that the most enduring-and dangerous - impact" of the majority opinion was to upset the relationship between Congress and the Judiciary. ${ }^{183}$ Because the Rules Enabling $\mathrm{Act}^{184}$ was "designed to foster a uniform system of procedure throughout the federal system," he said the Act "hardly contemplates" a broad, amorphous definition of inherent power. ${ }^{185} \mathrm{He}$ concluded that "Congressional concern for uniformity of practice in the federal courts" would be undermined as each individual court might "march to its own drummer." 186

In dissent, Judge Manion lamented "judicial high-handedness," additional expense to litigants, and no "appearance of fairness." $187 \mathrm{He}$ opined that inherent power cannot be "a license for federal courts to do whatever seems necessary to move a case along." "188 Rather, it should only be employed "to fill gaps left by statute or rule." ${ }^{189}$ Thus, "where a statue or rule specifically addresses a particular area, it is inappropriate to invoke inherent power to exceed the bounds the statute or rule sets."190

The Heileman opinions show how written civil procedure guidelines reflecting a narrow vision of civil trial courts can result in confusion and disparity where certainty and equality are desirable. ${ }^{191}$ Imagine how the

181. Id. at 661-62. Recognizing such potential problems, another appellate court determined that some such exercises of inherent power (in that case, to order compulsory nonbinding mediation) should be accompanied "in advance" by judicially dictated "reasonable" limits (e.g., time and expense). In re Atlantic Pipe Corp., 304 F.3d 135, 147 (1st Cir. 2002).

182. Heileman, 871 F.2d at $662-63$.

183. Id. at 665 (Ripple, J., dissenting).

184. 28 U.S.C. $\$ 2072(2000)$.

185. Heileman, 871 F.2d at 665 (Ripple, J., dissenting).

186. Id. at 666. Of course, nothing close to absolute uniformity is desirable, or even contemplated by Congress, as evidenced by its compelling individual district court civil justice expense and delay reduction plans covering matters such as compelled attendance at settlement conferences. See, e.g., 28 U.S.C. $\S 473$ (b)(5) (2000) ("“A] requirement that, upon notice by the court, representatives of the parties with authority to bind them in settlement discussions be present or available by telephone during any settlement conference.").

187. Heileman, 871 F.2d at 670 (Manion, J., dissenting).

188. Id. at 666

189. Id.

190. Id.

191. Certainly, broader guidelines expressly covering all who are "legally interested" could arise under local court rules. See, e.g., Mulligan v. Piczon, 739 A.2d 605, 610 (Pa. Commw. Ct. 1999) (relying on a local court rule which says "the party or a person with full settlement authority shall accompany the attorney to the pretrial conference" (emphasis omitted)). However, uniform local 
opinion would have read if the court had not only compelled the attendance of the defendant's insurer, but also of the plaintiff's insurer. A situation like this would occur if the plaintiff's insurer had compensated the plaintiff for injuries caused by the defendant and had a lien to recover such payments. ${ }^{192}$

\section{B. A New Vision in a New Model Judicial Code}

Judicial settlement guidelines should allow participation of all who are "legally interested," as contemplated in the 1972 Code. ${ }^{193}$ These guidelines should also recognize that settlements may encompass matters factually related to the pending claims, even where only the pleaded claims may be tried on the merits. Professor Chayes did not articulate this vision. The 1924 Canons more clearly suggested the appropriateness of such guidelines than did the 1990 Code, with its commentary. There are ways to remodel the traditional vision of trial court conduct. A new vision should include not only all those with legal interests, but also all disputes that might become "matters under submission" under the 1972 Code. ${ }^{194}$

One way to a new vision of trial courts is through the inevitable state-by-state deliberations on the new ABA initiative regarding the Model Code of Judicial Conduct. The study commission specifically invited comments in a few areas, including "what role judges should play in encouraging parties to settle" civil cases. ${ }^{195}$ Unfortunately, the

rules are rare so that at least some uncertainty and disparity will continue even should local rules proliferate. Local court rulemaking on federal district court authority to compel nonbinding forms of alternative dispute resolution, as well as the split in federal case precedents on such judicial authority, are discussed in Amy M. Pugh \& Richard A. Bales, The Inherent Power of the Federal Courts to Compel Participation in Nonbinding Forms of Alternative Dispute Resolution, 42 DUQ. L. REV. 1, 7-10, 14-19 (2003). The article also suggests amendments to the Alternative Dispute Resolution Act of 1998 and to FRCP 16 in order to codify the positive inherent power case precedents. $I d$. at $24-25$.

192. Of course, some eyes might behold in FRCP 16 what most others never see. In Lockhart v. Patel, 115 F.R.D. 44 (E.D. Ky. 1987), the trial judge seemingly found the version of FRCP 16 applied in Heileman to be clear as a bell. See id. at 46 (declaring that the authority to order attendance of "insurers at settlement conferences ... is so well established as to be beyond doubt" and suggesting there were few cases under the 1983 version of FRCP 16 "because the text of the Rule is so clear as to require little interpretation").

193. Code of Judicial Conduct Canon 3A(4) (1972).

194. Id. at Canon $3 \mathrm{~A}(5) \mathrm{cmt}$. For a proposal to amend the Model Code of Judicial Conduct regarding judicial settlement activity in civil cases, see Honorable John C. Cratsley, Judicial Ethics and Judicial Settlement Practices: Time for Two Strangers to Meet, 21 OHIO ST. J. ON DisP. ReSOL. 569,594 (2006), which proposes a bar on any judge trying a case where earlier personal settlement facilitation activity occurred.

195. Judicial Code Commission Releases Draft Proposal to Amend Parts of Code, 20 ABA/BNA LAW. MANUAL ON PROF. CONDUCT 262, 263 (2004) 
commission failed to speak loudly on all those with legal interests in pending civil actions and on all matters relevant in pending civil actions, including new claims, with or without nonparties, that are factually related to pending claims. Canon 2 of its December 2005 draft continues to speak of judicial duties as involving "Adjudication"196 and "Administration."197 While the rules and comments at times speak to "matters assigned,"198 any person "who has a legal interest," 199 and "participants" 200 in judicial proceedings, within the section on adjudication they focus more on the "rights of litigants," 201 ensuring the rights of the parties to be heard, ${ }^{202}$ the settlements of "parties," 203 how parties should not be coerced into settlement, ${ }^{204}$ ex parte communication barriers and procedures involving "parties," 205 separate conferencing "with the parties and their lawyers in an effort to settle matters pending," 206 "personal bias or prejudice concerning a party or a party's lawyer," 207 a judge's "economic interest . . . in a party to the proceeding," 208 campaign contributions by "a party" or "a party's lawyer," 209 and a procedure whereby "parties" waive their concerns regarding judicial disqualifications. ${ }^{210}$

Incidentally, the December 2005 draft of a new Model Code of Judicial Conduct also follows its predecessors by failing to make a clear distinction between adjudications of civil and criminal cases. The applicable procedures are dramatically different. In criminal cases, unpresented claims are not adjudicated, judges are not proactive in facilitating settlements, lawyers do not settle on behalf of their clients, and remedial and punitive orders are generally enforced outside of the trial courts.

If the Model Code of Judicial Conduct and other ABA pronouncements like the Standards Relating to Trial Courts, the

196. 2005 Draft, supra note 42, at Canons 2.05-12.

197. Id. at Canons 2.13-20.

198. Id. at Canon 2.05.

199. Id. at Canon 2.09(A).

200. Id. at Canon $2.10 \mathrm{cmt} 3$.

201. Id. at Canon $2.05 \mathrm{cmt} .1$.

202. Id at Canon 2.09

203. Id. at Canon $2.09 \mathrm{cmt} .2$.

204. Id. at Canon 2.09(B).

205. Id. at Canon 2.10(A).

206. Id. at Canon 2.10(A)(3).

207. Id. at Canon 2.12(A)(1).

208. Id. at Canon 2.12(A)(3).

209. Id. at Canon 2.12(A)(4).

210. Id. at Canon 2.12(C). 
descriptions of private civil case resolutions by academicians like Professor Chayes, and similar visions of American trial courts were all broadened to encompass those with legal interests and all matters that might be resolved amicably, if not tried, in civil cases, then it is more likely that written civil procedures laws, such as FRCP 16, would more comprehensively speak to civil case practices and would be a "more accurate reflection of actual practice." "11 Altering traditional perspectives would not be difficult. The Model Code of Judicial Conduct could speak to civil case responsibilities generally in a section on civil case resolution rather than in sections on adjudication and administration. Within this new section, at least three avenues of civil case resolution should be recognized: de novo, appellate review, and arbitration confirmation. Within the de novo category, criminal cases and civil cases would be separated. For civil cases subject to a de novo look, the major dispute resolution techniques should be separated, including pronouncements on adjudication on the merits (e.g., summary judgement, trial by jury, and bench trial), settlements, and resolutions not on the merits (e.g., dismissals on venue or jurisdiction grounds, for pleading deficiencies, or as sanctions for litigation misconduct).

Within the settlement principles, distinctions should be drawn between wholly private settlements (no judicial involvement) and judicially facilitated settlements (e.g., via devices such as judicial settlement conferences, court-compelled arbitrations, and court-annexed mediations). Distinctions should be drawn between the various judicialfacilitation devices on questions like who may preside and whether only pleaded or otherwise presented claims may be considered. Further distinctions seem better addressed in civil procedure laws rather than in the judicial conduct standards. As well, distinctions should be drawn generally between settlements which may or may not prompt future same-case enforcement (e.g., where a settlement breach may be enforced in the very same case in which the settlement arose, thus obviating the need for a new civil action). Again, civil procedure laws seemingly would better speak to more particular issues.

Within the de novo principles involving adjudications on the merits, civil disputes might be distinguished between those involving only named parties, only pleaded or otherwise presented claims, or only nonparties (where some such disputes might only be settled, as they could never be tried on the merits). Within the de novo principles involving resolutions not on the merits, discretionary versus mandatory 
adjudicatory jurisdiction could generally be addressed, as well as full faith and credit/comity concerns.

\section{New Civil Case Settlement Guidelines}

With new visions of civil trial courts, new and more comprehensive written guidelines on civil case resolutions will be easier to promulgate. As to judicial settlement conferences in civil cases where there is some de novo authority over nonparties and unpleaded claims, ${ }^{212}$ the Heileman issue (who may be compelled to attend a judicial settlement conference) could be solved by a new rule or statute, modeled on - though different from-Michigan Court Rule 2.401(F). ${ }^{213}$ It could say:

For a conference at which meaningful discussion of settlement is anticipated, the court may direct that persons with authority to settle the pending claims, as well as representatives of lienholders, representatives of insurers, and others who are financially interested in the outcome of pending and related claims (1) be present at the conference or (2) be immediately available by telephone or otherwise. $^{214}$

As to both judicial settlement conferences and private settlement talks, on the requisites for a valid settlement agreement when there is possible same-case settlement enforcement, a new rule or statute, modeled on Texas Civil Procedure Rule 11, ${ }^{215}$ could say: "No complete or partial settlement will be enforced unless it be in writing, signed, and allowed by the court to be filed, or unless it be made in open court and entered of record." 216 Such requirements would eliminate the problems that arise when agreements, reached orally at judicial settlement conferences, are never written or recorded in open court, but are subject

212. But see Richard L. Marcus, Slouching Toward Discretion, 78 Notre DAme L. REV. 1561, 1611 (2003) ("To say that there is too much procedural discretion . . . leaves open the question of alternatives. Regarding case management . . . the critics have not offered many attractive options. Indeed, some seem to concede that the systemic changes that have led to the current situation do not admit of ready cures.").

213. Місн. СT. R. 2.401.

214. Id. Interestingly, some local court rules on civil claim settlement facilitation speak a lot more about settlement devices than about judicial settlement conferences. See, e.g., W.D. MicH. CIV. R. 16 (speaking at greater length of the alternative dispute resolution methods involving voluntary facilitative mediation, early neutral evaluation, case evaluation, and court-annexed arbitration than of settlement conferences - though for the latter the role of an insurer is at least recognized). All court-sponsored settlement devices merit at least some guidance from written laws as they all can present difficult issues involving uniform practices.

215. TEX. R. CIV. P. 11.

216. Id. 
to same-case enforcement. Here, the trial judges - unfortunatelybecome witnesses in the hearings over which they preside. While finding such an agreement potentially "enforceable," Judge Richard Posner opined, in Lynch, Inc. v. SamataMason Inc., ${ }^{217}$ that reliance on the trial judge's memory of settlement details is a troublesome way to establish settlement terms because "memory is fallible" and "trial judges have a natural desire to see cases settled and off their docket.",218 A recording of the settlement by a court reporter, he said, would have provided a "solid, indeed an unimpeachable, basis" for establishing the agreement and constitutes "standard practice" that "should be followed in all cases." 219

In addressing when a trial court can enforce a settlement in the same civil case in which it arose, a California statute could also be used as a model. Following California Civil Procedure Code 664.6, a same-case judicial enforcement rule or statute could say:

If parties [or others legally interested in] pending litigation stipulate, in a writing signed ... outside the presence of the court or orally before the court, for settlement of the case, or part thereof, the court, upon motion, may enter judgment pursuant to the terms of the settlement. If requested ... the court may retain jurisdiction ... to enforce the settlement until performance in full of the terms of the settlement.

In the federal district courts, where such enforcement typically would fall within the discretionary powers of the supplemental jurisdiction statute, ${ }^{221}$ a new statute or rule could also reflect guidelines on when and

217. 279 F.3d 487 (7th Cir. 2002) (employing Illinois contract law). A review of choice of law analyses for issues involving settlement contracts appears in Jeffrey A. Parness \& Matthew R. Walker, Enforcing Settlements in Federal Civil Actions, 36 IND. L. REV. 33, 47-49 (2003).

218. Lynch, 279 F.3d at 490.

219. Id. at 490-91. An earlier call for such a practice is found in Jeffrey A. Parness \& Austin W. Bartlett, The Authority of Illinois Lawyers to Settle Their Clients' Civil Claims: On Principles Not Quite Settled, 31 Loy. U. CHI. L. J. 199, 224 (2000). Cf. Ross v. Mavrakis, 799 N.E.2d 469, 478 (Ill. App. Ct. 2003) (trusting the trial judges to resolve disputes over whether agreements were reached and over their terms when there are no transcripts or written court orders on what was said at judicially managed settlement conferences).

220. CAL. Civ. Proc. CODE $\S 664.6$ (West Supp. 2006).

221. Of course, there may be no enforcement discretion where a settlement contemplates samecase judicial enforcement when only certain remedies are sought; here, the complainant may have discretion to pursue the limited remedies in the trial court where the settlement occurred or to pursue all remedies in a new trial court case. See, e.g., Paulucci v. Gen. Dynamics Corp., 842 So. 2d 797, 803 (Fla. 2003) (continuing jurisdiction to enforce can be "circumscribed by the terms" of the settlement). Thus, some complainants can seek settlement enforcement in the same trial courts if they seek compliance with settlement terms, but will need to initiate new cases where they urge the contracts are no longer valid (due to "material" breaches) or where they "seek general damages not specified" in the settlement agreements. $I d$. 
how these discretionary powers might be exercised. There should be greater opportunities in federal courts for trial judges to agree to enforce settlements of pleaded claims involving named parties than settlements involving nonparties and state law claims. A new law could also reflect the mechanics of how a trial judge retains enforcement jurisdiction, as there has been confusion in the lower-level federal courts over the techniques available. ${ }^{222}$ The foregoing illustrates only some of the possible new general civil procedure laws ${ }^{223}$ on settlements that could follow a new vision of civil trial courts. ${ }^{24}$

With a new vision of civil trial courts, additional guidelines might also be more easily pursued for nonsettlement issues involving nonparties and unpleaded claims over which there is currently some confusion. $^{225}$ For example, there is uncertainty concerning the type of hearing necessary when a plaintiff's insurer seeks to press a lien (arising from paid medical bills for example) against the monetary settlement recovered by the plaintiff in a tort case. A good example comes from Indiana where there is a lien reduction statute lacking detailed procedures. $^{226}$ As one state appeals court lamented:

The main problem in this case is the confusion on the part of both parties and the trial court as to what should have transpired at the November 18 hearing. We observe that this is likely because neither the Lien Reduction Statute itself nor case law interpreting it provide guidance as to how a proceeding to reduce a lien should be initiated and conducted. This lack of guidance left everyone unclear as to what

222. See Parness \& Walker, supra note 217 , at $40-43$ (discussing the retention of settlement enforcement jurisdiction). In retaining same-case enforcement jurisdiction in a rare case of de novo authority, the Supreme Court said in Alaska v. United States, 126 S. Ct. 1014, 1016 (2006): "The Court retains jurisdiction to entertain such further proceedings, enter such orders, and issue such writs as from time to time may be deemed necessary or advisable to effectuate and supplement this Decree and the rights of the respective parties. In all other respects, this Decree is final."

223. Other new general civil procedure or professional responsibility laws on settlements of pending civil cases could address such matters as settlements under seal, attorney civil claim settlement authority, and discretion to refuse to exercise enforcement jurisdiction when asked although it was earlier retained.

224. In the absence of written general norms, individual courts or individual judges have authority to develop special local norms through local rules (or standing orders, perhaps). See, e.g., CAL. 4TH Dist. CT. APP. Division ONE R. 4 (stating local rule for appellate level civil settlement conference procedures); CAL. 4TH Dist. CT. ApP. Division One INTERNAL OPERATING PROCEDURE IX (stating local rule for appellate level settlement conferences that are court initiated); ILL. 16TH J. CIR. R. 10.01 (pertaining to trial level civil case settlements on behalf of minors, wards, and disabled persons).

225. Even when there are written guidelines, they can be confusing. See, e.g., 770 ILl. Comp. STAT. ANN. 5/1 (West 2006) (recognizing an attorney's lien on the civil claims of a client, allowing an attorney to seek enforcement in a related civil case after serving notice in writing to the "adverse party," and permitting the trial court to "adjudicate the rights of the parties" (emphasis added)).

226. See IND. CODE § 34-51-2-19 (1998) (lacking such procedures). 
should have taken place at the ... hearing. There seems to have been no consensus as to whether an evidentiary hearing with live testimony was required or whether affidavits, documentary evidence, and argument of counsel would suffice to resolve Needler's motion. Indeed, it appears based on what we can glean from the limited case law that motions or petitions to adjudicate liens under the Lien Reduction Statute have, at least in some cases, been resolved solely on the basis of documentary evidence and argument of counsel and not pursuant to a full evidentiary hearing. It also appears that proceedings to reduce a lien often take the form of a declaratory judgment action, as the trial court thought would be appropriate, but sometimes they appear to have been litigated through a motion ancillary to the underlying lawsuit, as Needler initiated this action. ${ }^{227}$

As to a defendant's insurer, there seems to be some uncertainty regarding the standards for notification of that insurer so that a plaintiff may recover later on a judgment entered against a defendant/insured. ${ }^{228}$ Proper regard for nonparty interests and their participation opportunities in civil actions would be enhanced with a new written norm that said at the outset of a case, or at least by the time of serious settlement talks, that trial judges and adversaries should be informed as to "all persons, associations of persons, firms, partnerships, corporations, guarantors, insurers, affiliates, parent or subsidiary corporations, or other legal entities who or which are financially interested in the outcome of the case." $^{229}$

\section{New Trial Court Guidelines for Reviewing Private Arbitrations and Agency Adjudications}

With a new vision of civil trial courts, it should also be easier to formulate better written guidelines for trial-court review of private arbitrations and agency adjudications. These guidelines would supplement existing statutory provisions, as in federal and state arbitration and administrative procedure acts.

Concerning private arbitrations, the general guidelines on confirmation procedures typically should be comparable for arbitrations

227. Principal Life Ins. Co. v. Needler, 816 N.E.2d 499, 503-04 (Ind. Ct. App. 2004) (citation omitted); $c f$. N.J. Stat. Ann. § 2A:13-5 (West 2000) (stating when an attorney's lien is erected and how an attorney petitions the court to determine and enforce a lien), noted in Levine v. Levine, 884 A.2d 222, 226-29 (N.J. Super. Ct. App. Div. 2005).

228. See, e.g., Vega v. Gore, 730 N.E.2d 587, 590 (Ill. App. Ct. 2000) (distinguishing between inadequate notice of the occurrence prompting a lawsuit and notice of the lawsuit in a timely way).

229. N.D. TEX. LOC. R. 3.1(f), 7.4 (stating that affirmative and responsive pleadings must include this information, although the primary purpose seems to be to ensure judicial independence). 
under general federal and state arbitration acts as the proarbitration policies are substantially similar. ${ }^{230}$ While general statutes or court rules on proceedings to compel arbitration or to confirm an arbitration award are not plentiful, there are some existing laws that could serve as models in areas of uncertainty. ${ }^{231}$ For example, there is some "alarm" over federal courts that too easily vacate arbitration awards ${ }^{232}$ as well as some confusion about whether the FAA has a one-year statute of limitations for judicial confirmation proceedings. ${ }^{233}$ On vacating arbitration awards, Iowa provisions seemingly speak more precisely than the FAA. ${ }^{234}$ On timing, New York provisions seem clearer. ${ }^{235}$ Moreover, there is unfortunately much confusion in the use of the term "arbitration agreement," rather than the more precise term "arbitration clause," in articulating judicial and arbitrator rules. ${ }^{236}$

230. These acts are similar as most state laws are modeled on the Uniform Arbitration Act (UAA), which itself generally follows the FAA. But see Allied-Bruce Terminix Cos. v. Dobson, 513 U.S. 265, 269 (1995) (noting the Supreme Court of Alabama has held that the FAA preempted an Alabama statute that made written predispute arbitration agreements invalid in Alabama under ALA. CODE § 8-1-41(3) (1989)).

231. Besides the general state laws noted below, there are also special arbitration laws. See, e.g., PA. R. CIV. P. 1326-1331 (stating procedure to compel arbitration and confirm an arbitration award in a consumer credit transaction).

232. See Pamela A. MacLean, Vacated Arbitration Awards Brings Alarm, NAT'L L.J., Feb. 6, 2006, at 4 (reporting on and examining Michigan Family Resources, Inc. v. Service Employees International Union Local 517M, 438 F.3d 653, 661-63 (6th Cir. 2006) (Sutton, J., concurring), which opined that the circuit court approach "has made it easier to vacate an arbitration award on the merits than the Supreme Court meant it to be" and calling for full circuit court review)); see also B.L. Harbert Int'l, L.L.C. v. Hercules Steel Co., 441 F.3d 905, 914 (11th Cir. 2006) (expressing exasperation at "those who would attempt to salvage arbitration losses through litigation that has no sound basis in the law"); Stephen L. Hayford, Law in Disarray: Judicial Standards for Vacatur of Commercial Arbitration Awards, 30 GA. L. REV. 731, 734-98 (1996) (examining the willingness of courts to vacate arbitration awards); Paul F. Kirgis, The Contractarian Model of Arbitration and Its Implications for Judicial Review of Arbitral Awards 17 (St. John's Univ. Sch. of Law Legal Studies Research Paper Series, Paper No. 06-0037, 2006), available at http://SSRN.com/abstract=877171 (discussing how courts find grounds for overturning awards).

233. MBNA Am. Bank, N.A. v. Rogers, 835 N.E.2d 219, 221-22 (Ind. Ct. App. 2005) (finding no Supreme Court or Seventh Circuit precedents, though the Second Circuit had ruled that the FAA created a one-year statute of limitations).

234. IowA CodE ANN. § 679A.12 (West 1998 \& Supp. 2006); see also B.L. Harbert, 441 F.3d at 910-13 (recognizing that in addition to the four statutory grounds in the FAA for judicial vacatur of arbitration awards, "there are three non-statutory grounds," where, one, manifest disregard of the law, was unfortunately confusing to one of the parties due to "speculative dicta" in an earlier precedent).

235. N.Y. C.P.L.R. 7502(a)(iv) (McKinney 2006) (confirming arbitration award).

236. See, e.g., Higgins v. Superior Court, 45 Cal. Rptr. 3d 293, 303 (Ct. App. 2006) ("Uncertainty can become especially pronounced when parties or courts use the term 'arbitration agreement,' when 'arbitration clause' might be more precise."); see also Fox Int'l Relations v. FISERV Secs., 418 F. Supp. 2d 718, 724 (E.D. Pa. 2006) (stating that while it "may seem paradoxical," a court may "enforce an arbitration agreement in a contract that the arbitrator later finds to be void" and a court "may deny effect to an arbitration provision in a contract that the court later finds to be perfectly enforceable"). 
In February 2006, the Eleventh Circuit, while recognizing some confusion over the nonstatutory grounds for vacating FAA-guided arbitrations, ${ }^{237}$ suggested there also be consideration of new, preferably written, guidelines on sanctioning those frivolously opposing final arbitration awards. Specifically, it said:

Courts cannot prevent parties from trying to convert arbitration losses into court victories, but it may be that we can and should insist that if a party on the short end of an arbitration award attacks that award in court without any real legal basis for doing so, that party should pay sanctions. A realistic threat of sanctions may discourage baseless litigation over arbitration awards and help fulfill the purposes of the pro-arbitration policy contained in the FAA. It is an idea worth considering. ${ }^{238}$

It proceeded to declare itself "ready, willing, and able to consider imposing sanctions in appropriate cases," having issued a "notice and warning." 239 As with defenses in certain de novo civil actions, there may be an empirical, or other public policy, basis for treating specially, and with greater wariness, objections to certain arbitration confirmation proceedings.

In settings where there are superseding arbitration statutes, ${ }^{240}$ as with health care $^{241}$ and employment, ${ }^{242}$ special statutes or court rules on sanctioning those opposing arbitration confirmations may also be in order where the superseding statutes are silent. Again, while there are not special statutes or court rules at every turn, there are a few illustrations. For example, effective February 1, 2006, Pennsylvania has adopted new written court rules on compelling arbitration and confirming arbitration awards in consumer credit transactions. ${ }^{243}$

237. B.L. Harbert, 441 F.3d at 914 (acknowledging "speculative dicta" providing appellant with "a little cover" to justify its appeal of the arbitration ruling).

238. Id. at $913-14$.

239. Id. at 914 .

240. Superseding statutes may exempt from general arbitration act provisions several differing types of arbitration pacts at once. See, e.g., Tex. Civ. PRAC. \& REM. CodE ANN. § 171.002(a)(1), (3)-(4) (Vernon 2005) (making general arbitration act inapplicable to employer/labor union pacts, typical claims for personal injury, and claims for workers' compensation benefits).

241. See, e.g., 710 Ill. Comp. StAT. ANn. 15/1-14 (West 1999) (health care arbitration agreements).

242. See, e.g., MASS. GEN. LAWS ANN. ch. 251 , $§ 1$ (West 2004) (addressing inapplicability of UAA to "collective bargaining agreements to arbitrate").

243. PA. R. CIV. P. 1326-1331. The Civil Procedure Rules Committee's explanatory comment indicates that the new rules should "minimize court involvement and provide quicker and cheaper relief to the litigants." PA. R. CIV. P. $1326 \mathrm{cmt}$. It also recognizes that "procedures that work for consumer credit transactions may not work for all types of matters involving statutory [UAA] and 
Concerning agency adjudications, general guidelines on trial court review procedures should be substantially similar and typically included within general administrative procedure laws. ${ }^{244}$ Unlike original subject matter jurisdiction over "civil actions",245 or "justiciable matters,", 46 appellate, or appellate-type, review authority of general trial courts over administrative agency adjudications, and other administrative agency "action," 247 is usually guided by legislation. ${ }^{248}$ Yet where the enabling legislation for general trial court review of certain administrative agency actions contains unique provisions (e.g., greater judicial deference than usual to a particular agency's actions on legal issues due to that agency's very special experience or expertise), then special statutory review procedures may be needed. ${ }^{249}$

Re-envisioning American trial courts so they are perceived as significant overseers of administrative agency actions could facilitate new written guidelines in areas of current uncertainty. For example, there are now "muddled" judicial analyses regarding the level of federal court deference due a federal agency's interpretation of the statutes it administers. ${ }^{250}$ An administrative procedure act could be amended to clarify the circumstances under which agency interpretations carry the "force of law" to which courts must defer. ${ }^{251}$ Amendments could speak

common law arbitration." Id.

244. See, e.g., 735 Ill. CoMP. StAT. AnN. 5/1-101, /3-102 (West 2003) ("Administrative Review Law," guiding many judicial reviews of final agency decisions, is situated within the "Code of Civil Procedure")

245. See, e.g., ALA. CONST. art. VI, $§ 6.04$ ("Circuit court" has jurisdiction "in all cases except as may otherwise be provided by law"); CAL. CONST. art. VI, § 10 ("Superior courts" have jurisdiction over "causes"); COLO. CONST. art. VI, $\S 9$ (district courts have "original jurisdiction in all civil, probate, and criminal cases"); D.C. CONST. art. IV, § 3(A) ("Superior Court shall have jurisdiction of civil actions or other matters, at law or in equity, brought in the State . ...").

246. See, e.g., ILL. CONST. art. VI, $\S 9$ (circuit courts have original jurisdiction over "all justiciable matters"); KY. CONST. $§ 112(5)$ (circuit court has "original jurisdiction of all justiciable causes").

247. See, e.g., ILL. CONST. art. VI, § 9 (circuit courts may be delegated power to review "administrative action").

248. See, e.g., FLA. CONST. art. V, § 5(b) (circuit courts have power to review "administrative action"); ILL. CONST. art. VI, $\S 9$ (circuit courts "shall have . . . power to review administrative action as provided by law"). Of course, some final agency actions may be reviewable, in the first instance, in intermediate appellate courts. See, e.g., ILL. ConST. art. VI, $\S 6$ ("The Appellate Court shall have such powers of direct review of administrative action as provided by law."); 5 ILL. COMP. STAT. ANN. 315/11(g) (2005) (allowing Appellate Court review of final unfair labor practice orders of the Local Labor Relations Board).

249. See, e.g., KAN. STAT. ANN. § 77-618 (1997) (judicial review of agency factfinding differs, e.g., for workers' compensation, employment discrimination, and driver's license termination proceedings than for other agency proceedings).

250. Lisa Schultz Bressman, How Mead Has Muddled Judicial Review of Agency Action, 58 VAND. L. REV. 1443, 1475 (2005).

251. See United States v. Mead Corp., 533 U.S. 218, 232 (2001) (stating that the general 
to the particular agency lawmaking techniques that warrant even more deference (e.g., anything done procedurally beyond notice-and-comment rulemaking or bare bones informal adjudication). Amendments could also speak more generally to the attributes of lawmaking procedures that must be considered in determining whether greater deference is warranted. ${ }^{252}$

As well, new written guidelines could be contemplated for the standards of federal judicial review applicable to agency determinations of factual issues during adjudications. For example, the federal Administrative Procedure Act provides, in its "scope of review" section, that an agency action not determined on the record be set aside if "arbitrary, capricious, an abuse of discretion, or otherwise not in accordance with law," 253 while an agency action determined on the record be set aside if "unsupported by substantial evidence." 254 While the congressional language seemingly suggests differing levels of scrutiny, many federal judges find "the substantial evidence test and the arbitrary or capricious test are one and the same." ${ }^{255}$ Could new written norms help overcome the confusion?

Though there is good reason for state trial courts to operate like federal trial courts when reviewing final agency actions, ${ }^{256}$ very different standards should sometimes apply. The comparable Illinois "scope of review" statute simply says that during judicial review of "any final administrative decision," the "findings and conclusions of the administrative agency on questions of fact shall be held to be prima facie true and correct." ${ }^{257}$ While Illinois courts often use the federal court approach on deference to agency legal analysis, ${ }^{258}$ on agency factfinding, Illinois precedents vary, speaking at times of a "manifest weight of the

rulemaking power authorizes regulation with "force of law").

252. See Bressman, supra note 250 , at $1444-50$ (discussing judicial deference to administrative agency rulemaking and adjudication).

253. 5 U.S.C. $\$ 706(2)(\mathrm{A})(2000)$.

254. Id. $\S 706(2)(\mathrm{E})$.

255. See, e.g., Ass'n of Data Processing Serv. Orgs., Inc. v. Bd. of Governors, 745 F.2d 677, 683 (D.C. Cir. 1984) (opinion by then-Circuit Judge Scalia).

256. Of course, no comparability should necessarily follow where similar agency actions (e.g., rules) originate from very different procedures (e.g., in some states there are no distinctions between formal and informal (on and off the record) agency rulemaking).

257. 735 Ill. COMP. Stat. ANN. 5/3-110 (West 2003). Incidentally, such a decision does not encompass general rulemaking or regulations concerning internal management that do not affect private rights. $I d$. at 5/3-101.

258. See, e.g., Church v. State, 646 N.E.2d 572, 577 (Ill. 1995) (stating that a state court will not substitute its own construction of a statutory provision for a reasonable interpretation adopted by the agency charged with the statute's administration). 
evidence" test ${ }^{259}$ and at times of a "substantial evidence" test. ${ }^{260}$ Reenvisioning American trial courts might help focus civil procedure lawmakers so that they clarify uncertain guidelines on judicial review of final administrative actions.

\section{CONCLUSION}

Today American trial courts are trying less, and managing more, private civil cases. They are also losing such cases to other dispute resolvers. The traditional role of the trial judge as chiefly a neutral, detached, and passive adjudicator for private civil cases has given way to the trial judge who is a more active case manager, a more aggressive settlement facilitator, and an appellate-type reviewer of case decisions made elsewhere. Unfortunately, contemporary-written civil procedure laws do not reflect this new vision. They increasingly reflect legend rather than reality. New general perspectives on contemporary trial court decisionmaking would help civil procedure lawmakers better formulate written procedural law guidelines for trial courts. In particular, there is a need for new written laws on trial court settlements as well as on trial court oversight of earlier private arbitrations and administrative agency actions.

259. See, e.g., Kloss v. Bd. of Fire \& Police Comm'rs, 449 N.E.2d 845, 848 (Ill. 1983) (indicating that review of an administrative proceeding initially requires an inquiry into whether the administrative agency's findings of fact are contrary to the manifest weight of the evidence); Basketfield v. Police Bd., 307 N.E.2d 371, 375 (Ill. 1974) (specifically rejecting substantial evidence test).

260. City of Burbank v. Ill. State Labor Relations Bd., 538 N.E.2d 1146, 1150 (Ill. 1989), superseded by statute, Illinois Public Labor Relations Act, 5 ILl. COMP. STAT. AnN. 315/11(e) (West 2005). 